\title{
INDEMNIZACIÓN DE PERJUICIOS POR VICIOS REDHIBITORIOS EN EL CóDIGO CIVIL ChILENo-COLOMBIANO*
}

\section{COMPENSATION FOR LATENT DEFECTS ACCORDING TO THE CHILEAN AND COLOMBIAN CIVIL CODES}

\author{
Jorge Oviedo-Albán** \\ Fecha de recepción: 5 febrero de 2014 \\ Fecha de aceptación: 9 de abril de 2014 \\ Disponible en linea: 30 de junio de 2014
}

\section{Para citar este artículo/To cite this article}

\author{
Oviedo-Albán, Jorge, Indemnización de perjuicios por vicios redhibitorios \\ en el Código Civil chileno-colombiano, 129 Vniversitas, 239-274 (2014). \\ http://dx.doi.org/10.11144/Javeriana.VJ129.ipvr \\ doi:10.11144/Javeriana.VJ129.ipvr
}

* Este artículo es resultado del proyecto de investigación La garantía por vicios ocultos en la compraventa, auspiciado por la Universidad de La Sabana.

** Doctor en derecho y magíster en derecho privado, Universidad de los Andes (Santiago de Chi1e). Abogado y especialista en Derecho Comercial, Pontificia Universidad Javeriana (Bogotá). Profesor asociado y Director de la Maestría en Derecho de la Empresa y de los Negocios en la Universidad de La Sabana. Correo electrónico: jorgeoa@unisabana.edu.co 


\section{RESUMEN}

En el presente artículo, el autor analiza el alcance de la indemnización de perjuicios por vicios ocultos según su regulación en el Código Civil vigente en Chile y Colombia y busca demostrar la independencia de tal acción indemnizatoria, de manera que esta surge no por la presencia misma de los vicios y tampoco por el incumplimiento de una obligación de calidad o idoneidad, sino por incumplimiento de un deber específico de información asumido por los vendedores que conocían o debían conocer el vicio. Ello lleva a tratar de establecer si pueden identificarse diferentes escenarios de indemnización a partir de la presencia de defectos ocultos de la cosa en el contrato de compraventa. Para lo anterior, este artículo se basa en un análisis de las reglas vigentes en el Código Civil chilenocolombiano, de la doctrina y la jurisprudencia existente en ambos países y de algunos elementos de Derecho comparado que permitan identificar críticamente las diversas soluciones propuestas en torno a este tema.

Palabras clave: vicios redhibitorios; indemnización de perjuicios; contrato de compraventa 


\section{ABSTRACT}

This article analyzes the extent of compensation in case of latent defects according to the Civil Code in Chile and Colombia. It also seeks to demonstrate the independence of such compensatory action, which does not arise by the sole presence of the vices nor for the breach of an obligation of quality, but for the breach of a specific duty of disclosure assumed by the seller who knew or should have know the vice. This leads to try to establish whether different scenarios can be identified for compensation based on the presence of hidden defects of the thing in the purchase agreement. This article is based on an analysis of the existing rules in the Chilean and Colombian Civil Codes, in the doctrine and existing jurisprudence from both countries, as well as in some elements of comparative law that allow to critically identify the various solutions proposed in relation to this matter.

Keywords: latent defects; compensation for damages; contract of sale

\section{SUMARIO}

INTRODUCCIÓN.- I. RESPONSABILIDAD POR DOLO O CULPA DEL VENDEDOR.- $A$. El deber precontractual de información como fundamento.- B. Sobre la prueba del dolo y de la culpa del vendedor.- C. Componentes de la indemnización.II. RESPONSABILIDAD POR DAÑOS OCASIONADOS POR LA COSA VICIOSA.- $A$. La solución adoptada por el Derecho italiano, francés y alemán.- B. La solución propuesta para el derecho chileno y colombiano.- III. EL CARÁCTER PRINCIPAL O ACCESORIO DE LA INDEMNIZACIÓN.- $A$. La tendencia en el derecho comparado.- B. La cuestión en la doctrina y jurisprudencia de Chile y Colombia.- Conclusiones.- Bibliografía. 


\section{INTRODUCCIÓN}

El artículo 1861 del Código Civil chileno (en adelante C.C. chil.), correspondiente al 1918 del Código Civil colombiano (en adelante C.C. col.), establece que en caso de vicios redhibitorios el vendedor deberá al comprador, no solamente la restitución o la rebaja del precio, cuando el comprador optare bien sea por la acción redhibitoria o la quanti minoris, consagradas en los artículos 1857 C.C. chil.; 1914 C.C. col., sino también indemnizar los perjuicios en los eventos en que el vendedor los conocía y no los declaró o estos eran tales que haya debido conocerlos por razón de su profesión u oficio. Tales perjuicios están relacionados con la falta de calidad o idoneidad de la cosa que por ello genera un daño al comprador al disminuir e impedir su utilización para los fines contractuales.

Esta norma genera varios interrogantes, en torno a determinar si limita el acceso a la indemnización de perjuicios general por incumplimiento consagrada en el artículo 1489 C.C. col; 1546 C.C. col., además de la reparación a causa de los daños que la cosa viciosa pudiera generar al comprador o a otros de sus bienes y en todo caso si es una acción independiente o complementaria de las edilicias, como también el término de prescripción de la misma.

El objetivo de este artículo consiste en demostrar la independencia de tal acción indemnizatoria de perjuicios por vicios redhibitorios, de manera que esta surge no por la presencia misma de los vicios y tampoco por el incumplimiento de una obligación de calidad o idoneidad, que autorizaría al comprador para pedir una indemnizacion según las reglas generales de incumplimiento, sino por la violación de un deber específico de información asumido por ciertos vendedores ${ }^{1}$. Ello lleva a tratar de establecer si pueden identificarse diferentes escenarios de indemnización a partir de la presencia de defectos ocultos de la cosa en el contrato de compraventa. Para lo anterior, este artículo se basa en un análisis dogmático de las reglas vigentes en el Código Civil chileno - colombiano, además de la doctrina

1 Es la fórmula normalmente empleada por los Códigos. Cfr. artículo 1645 del Code; artículo 1486 (II) del Código Civil español y artículo 1494 del Código Civil italiano. 
y jurisprudencia existente en ambos países, que permitan identificar críticamente las diversas soluciones propuestos en torno a este tema. Adicionalmente, se acude al Derecho comparado, con el fin de indagar por el estado de la cuestión en algunos de los países más representativos de la tradición europeo continental y en los principales instrumentos internacionales del Derecho de contratos, con el fin de entontrar elementos interpretativos de las normas nacionales. Cabe aclarar, que la responsabilidad por vicios ocultos del bien en el Derecho contemporáneo no puede limitarse a la indemnización consagrada en el Código Civil y sin duda cabe analizar su relación con la responsabilidad por productos defectuosos. De todas maneras, dicho tema si bien es advertido en este artículo, no pretende ser desarrollado en el mismo y deberá ser objeto de tratamiento posterior.

El trabajo está estructurado en tres puntos de la siguiente manera: primero se analiza la responsabilidad por dolo o culpa del vendedor, al establecer que la responsabilidad por perjuicios a propósito de los vicios ocultos se basa en la omisión de un deber precontractual de información (I). Posteriormente, se hace una revisión de la responsabilidad por daños ocasionados por la cosa viciosa (II) para en tercer lugar analizar el carácter principal o accesorio de la indemnización (III). El artículo termina con una relación de bibliografía y jurisprudencia analizadas.

I. Responsabilidad por dolo o culpa del vendedor

El primer escenario de responsabilidad por vicios ocultos, es el derivado de los eventos contemplados en los artículos 1861 C.C. chil.; 1918 C.C. col., según los cuales la indemnización de perjuicios por vicios redhibitorios solamente cabe para los eventos en que el vendedor los conocía y no los declaró o debía conocerlos en razón de su profesión u oficio y no por la mera presencia de los mismos, por lo cual el fundamento de esta responsabilidad no puede encontrarse en las obligaciones derivadas del contrato de venta sino que tiene naturaleza precontractual originada en el dolo o culpa del vendedor ${ }^{2}$.

2 Para la distinción entre violación dolosa o culposa del deber de informar del vicio véase Guzmán Brito, Alejandro, "Sobre la relación entre las acciones de saneamiento de los vicios 
Corresponde indagar por su fundamento y alcance, aspectos a los que se hace referencia a continuación.

\section{A. El deber precontractual de información como fundamento}

De las disposiciones legales citadas puede inferirse que sobre ciertos vendedores: los que conocían el vicio o debían conocerlo por ser vendedores profesionales, pesa un deber de información en virtud del cual deben dar noticia al comprador sobre su existencia. Omitirlo, significa comprometer su responsabilidad para con el comprador. Cabe adicionar que hay cierto consenso en la doctrina moderna acerca del fundamento de la responsabilidad del vendedor por vicios redhibitorios, fundándola no en la presencia del vicio en sí mismo, sino en el incumplimiento de un deber precontractual de información ${ }^{3}$. También la Corte Suprema de Justicia colombiana lo ha entendido de esa forma. Así lo ha señalado en un fallo de 2009 , en un caso relativo a

redhibitorios y las acciones comunes de indemnización, con especial referencia a su prescripción”, en Revista chilena de Derecho Privado, 9, (2007), pág. 102, quien señala que cuando el vendedor conoce el vicio y no lo declara incurre en dolo y cuando debía conocerlo por razón de su profesión u oficio, eso implica culpa. En la doctrina colombiana Gómez Estrada, aunque afirma que la resolución debiera poder conllevar la posibilidad para el comprador de demandar la indemnización de perjuicios, como una consecuencia derivada del incumplimiento del contrato por parte del vendedor, considera que la solución del Código es correcta, pues si al vendedor no puede imputarse culpa, no se le puede llamar a indemnizar. Gómez EsTRADA, CéSAR, De los principales contratos civiles, Temis, $4^{\mathrm{a}}$ edición, Bogotá, 2008, págs. 104 a 105.

3 Cfr. Díez - Picazo, Luis, Fundamentos del Derecho Civil patrimonial. IV. Las particulares relaciones obligatorias, Civitas, Thomson Reuters, Elcano, 2010, pág. 139. Verda y Beamonte, José Ramón de, Saneamiento por vicios ocultos. Las acciones edilicias, $2^{\mathrm{a}}$ edición, Aranzadi, Cizur Menor, 2009, págs. 210 a 212. VIsinTINI, Giovanna, La reticenza nella formazione dei contratti, Cedam, Padova, 1972, págs. 155 y sigs. También lo expresa así la doctrina reciente en Colombia y Chile. Rengifo Garcia, ERnesto, "El deber precontractual de información", en Realidades y tendencias del Derecho en el siglo XXI, Derecho Privado, t. IV, 1, AA. VV., Pontificia Universidad Javeriana, Temis, Bogotá, 2010, pág. 125. Barrientos Zamorano ha considerado en Chile, que la indemnización por vicios redhibitorios, se origina por violación de un deber de información. Barrientos Zamorano, Marcelo, Daños y deberes en las tratativas preliminares de un contrato, Legal Publishing, Santiago, 2008, págs. 78 a 79. Igualmente Barros Bourie, Enrique, Tratado de responsabilidad extracontractual, Editorial Jurídica de Chile, Santiago, 2006, págs. 1019 a 1020. DE la Maza Gazmuri, IÑIgo, "A propósito del artículo 1861", en Estudios de Derecho Civil V, Jornadas Nacionales de Derecho Civil, Concepción, 2009, Departamento de Derecho Privado Universidad de Concepción (Coordinador), Abeledo Perrot - Legal Publishing, Santiago, 2010, pág. 459. También de la Maza Gazmuri, IÑIGO, "La distribución del riesgo y la buena fe. A propósito del error, el dolo y los deberes precontractuales de información", en Revista de Derecho de la Pontificia Universidad Católica de Valparaíso, XXXVII, (2011), pág. 118. De la MAZa GaZmuri, IÑIGO, Los límites del deber precontractual de información, Civitas, Cizur Menor, 2010, págs. 69 a 104. 
una demanda de indemnización de perjuicios instaurada por el comprador de un inmueble a causa de la pérdida total del mismo ocasionada por la inestabilidad del suelo y defectos en la construcción manifestados con posterioridad a la entrega del bien. En la sentencia, la Corte Suprema afirmó que la indemnización no se deriva de la existencia del vicio sino del conocimiento o deber de conocerlo y su conducta omisiva ya sea deliberada o errónea, que compromete la responsabilidad del vendedor ${ }^{4}$.

La primera de las mencionadas, es una situación en la cual el vendedor obra dolosamente al ocultar el vicio o simplemente no declarar su existencia, de forma que el comprador no puede percibirlo a simple vista al momento de celebración del contrato $^{5}$. Ello daría a pensar que si se entiende en este caso la conducta dolosa del vendedor como maquinación fraudulenta para inducir al comprador a celebrar el contrato sin la cual éste no contrataría, se está frente a un vicio del consentimiento en el contexto del Código Civil, de manera que puede tener cabida además de la indemnización a la que se refiere la norma, una acción de nulidad, o si pueden acumularse alternativamente con la acción redhibitoria ${ }^{6}$.

En este se impone el criterio de la especialidad, por razón de estar dicha situación regulada en una norma especial como es el artículo 1861 C.C. chil.; 1918 C.C. col., en el cual se consagra

4 Corte Suprema de Justicia, Sala de Casación Civil, M.P. William Namén Vargas, 19 de octubre de 2009, Ref: 05001-2103-009-2001-00263-01, en Notinet. Finalmente la Corte no casó la sentencia del tribunal de apelación que reconoció la indemnización de perjuicios pero además decretó la resolución del contrato.

5 De hecho, la jurisprudencia chilena ha entendido que el dolo, tratándose de vicios ocultos, constituye requisito sine qua non, para la procedencia de la indemnización de perjuicios. Corte Suprema, 13 de enero de 1944, RDJ., t. 42, $2^{\text {a }}$ parte, secc. $1^{\text {a }}$, pág. 25. Según afirma de la Maza, se trata de una reticencia intencional. DE la MAZA Gazmuri, Los límites del deber precontractual de información, cit., pág. 83. Se trata de un "dolo in contrahendo", según la expresión utilizada por la doctrina para referirse a esta situación. También en otro trabajo al analizar el artículo 1861 del Código Civil de Chile, el autor precisa que este supuesto de responsabilidad se configura a partir del dolo del vendedor. DE LA MAZA GAZMURI, "A propósito del artículo 1861”, cit., pág. 458. Véase también: Llácer MATACÁs, MARÍA RosA, "El dolo en el saneamiento por vicios ocultos", en Anuario de Derecho Civil, t. XLV, f. IV, (1992), pág. 1504.

6 Cfr. Artículos 1458 y 1682 C.C. chil.; 1515 y 1741 C.C. col. En la doctrina colombiana, Pérez Vives afirmó que cuando se pruebe el dolo del vendedor, cabría interponer alternativamente cualquiera de las acciones: nulidad por dolo o hacer valer la garantía por vicios. PÉREZ VIVES, Álvaro, Compraventa y permuta en Derecho colombiano, $2^{\mathrm{a}}$ edición, Temis, Bogotá, 1953, $\mathrm{n}^{\circ}$ 362, pág. 400. 
que el comprador tendrá derecho a pedir una indemnización de perjuicios cuando el vendedor sabía de los vicios ocultos y no los declaró o debió haberlos conocido, en razón de su profesión u oficio, sin perjuicio de las acciones redhibitoria o la de rebaja de precio, que primarían sobre la nulidad proveniente del dolo. Esta indemnización también cubre el evento en que la cosa se destruye por causa del vicio. El artículo 1862 C.C. chil.; 1919 C.C. col., establece en la segunda parte que si la cosa pereciere por efecto del vicio inherente a ella, se seguirán las reglas del artículo precedente, por lo cual debe entenderse que el comprador de un bien destruido por causa del vicio solamente tendrá derecho a la indemnización si el vendedor lo conocía y no lo declaró o debía conocerlo.

El otro supuesto en el que queda comprometida la responsabilidad del vendedor, es cuando hay culpa por tratarse de alguien que debía o podía conocer los vicios en razón de su profesión u oficio, por lo cual cabría una "culpa in contrahen$d o$ ". En el Código Civil chileno - colombiano, a diferencia de otras legislaciones se incluyen expresamente las dos situaciones: el vendedor que conoció los vicios y no los declaró y también quien debía conocerlos, en razón de su profesión y oficio, por lo que en este Código no caben las discusiones que han tenido lugar en el Derecho español en relación a si el artículo 1486 (II), incluye o no la segunda situación, pues la norma se refiere a los vicios que el vendedor conocía y no los manifestó al comprador ${ }^{7}$. Tampoco el artículo 1645 del Código Civil francés menciona a los vendedores profesionales, cuestión subsanada por la jurisprudencia desde hace varias décadas al asumir que la competencia técnica del vendedor es un elemento acreditante

7 Sobre el particular Llácer MATACÁs, ob. cit., pág. 1505, al indicar que aunque el supuesto de desconocimiento imputable es posible teóricamente, el legislador español no lo recogió. En sentido contrario Morales Moreno, quien se refiere a una reticencia no intencional, en la que aunque no haya engaño, la buena fe impone ciertos deberes de mínima diligencia en el momento de celebración del contrato, y donde a pesar del desconocimiento, la ignorancia crasa lleva a que el deber de conocer se equipare al conocimiento, como en el caso de la condición de perito que ostente el vendedor frente a un comprador no perito. Morales Moreno, Antonio Manuel, "El dolo como criterio de imputación de responsabilidad al vendedor por defectos de la cosa", en Anuario de Derecho Civil, t. XXXV, f. III, (1982), págs. 641 a 646. Sobre el particular también de LA MAZA GAZMURI, Los límites del deber precontractual de información, cit., págs. 85 a 89 , en que el autor expresa argumentos para preferir la posición según la cual sí se entiende incluida dicha posibilidad en el mencionado precepto. 
del conocimiento del vicio por el mismo, de manera que se lo asimila al vendedor de mala $\mathrm{fe}^{8}$. En cuanto al Derecho italiano, el Código Civil consagra en el artículo 1494 en todo caso una presunción de conocimiento de los vicios y por ello obliga al vendedor a indemnizar los perjuicios, a menos que pruebe haberlos ignorado sin culpa. La interpretación de la doctrina y jurisprudencia italianas sobre esta norma ha sido asumir que tal presunción de conocimiento le impone al vendedor demostrar haber desarrollado la diligencia normal en relación con la actividad ejercitada para liberarse de la obligación de indemnización, en particular un comportamiento positivo encaminado a verificar el estado y cualidad del bien y controlar de modo adecuado la ausencia de vicio9.

Se puede asumir que los vendedores pueden o deben conocer los defectos de los bienes, en razón de su profesión u oficio, a partir de factores objetivos que permitan construir tal deber y presunción de conocimiento, para con base en estos derivar el deber de información de los defectos asumido por ellos. Tales factores pueden ser el que se trate de un comerciante, a quien se le puede atribuir responsabilidad por afirmar cualidades concretas que el bien no posee; porque sus aptitudes lo pueden llevar a descubrir los defectos fácilmente; por asumirse que debe seleccionar sus productos y evitar poner en venta bienes que resulten peligrosos o tratándose de un vendedor fabricante, en el que por su condición de perito se derive como consecuencia tal deber de conocimiento ${ }^{10}$.

8 Cfr., con referencia a fallos que así lo han considerado: Huet, JÉRôme, Les principaux contrats spéciaux, en Traité de Droit Civil sous la direction de Jacques Ghestin, $2^{\circ}$ edition, LGDJ, Paris, 2001, nº 11376, págs. 324 a 325. Faure AbBad, Marianne, Le fait générateur de la responsabilité contractuelle, LGDJ, Paris, 2003, nº 546, págs. 442 a 443.

9 Cfr., con indicación de fallos en este sentido: Agostinis, BARbara, La garanzia per i villi della cosa venduta. Le obligazioni del compratore. Artt. 1490 - 1499, Il Codice Civile, Commentario, fondato da Piero Schlesinger, diretto da Francesco D. Busnelli, Giuffrè, Milano, 2012, pág. 120, esp. nt. 12.

10 Alessandri Rodríguez, Arturo, De la compra - venta i de la promesa de venta, t. $2^{\circ}$, Imprenta litográfica Barcelona, Santiago, 1918, nº 1472, pág. 328. Morales Moreno, "El dolo como criterio de imputación...", cit., págs. 656 a 666. 


\section{B. Sobre la prueba del dolo y de la culpa del vendedor}

Cabe establecer si el comprador debe probar la mala fe del vendedor para la procedencia de la indemnización que en los dos casos planteados significaría deber probar el dolo, cuando el vendedor conocía el vicio y no lo declaró, o la culpa del que debía haberlo conocido por razón de su profesión u oficio.

En la doctrina colombiana Pérez Vives afirmó que el comprador deberá probar el conocimiento de los vicios por parte del vendedor, salvo en el caso en que debiera conocerlos por su profesión u oficio, pues allí habría una presunción de conocimiento de los mismos en su contra ${ }^{11}$. En idéntico sentido en Chile, Alessandri Rodríguez afirmó también que tratándose del vendedor profesional se presume el conocimiento de los vicios, derivando tal presunción de su posibilidad de tener noticia sobre los mismos, de tal manera que al comprador correspondería probar la existencia del vicio y el que por la profesión u oficio podía conocerlos ${ }^{12}$.

En la jurisprudencia chilena se ha asumido también dicha presunción de conocimiento de los vicios tratándose de vendedores profesionales ${ }^{13}$. De igual forma en la jurisprudencia colombiana en la que los fallos referidos a la indemnización de perjuicios insisten en que ésta se debe cuando el vendedor tenía conocimiento de ellos o ha debido tenerlos, por razón de su profesión u oficio ${ }^{14}$. En ninguno de estos fallos se ha requerido

11 Pérez Vives, ob. cit., nº 343, págs. 382 a 383. Igualmente Tamayo Jaramillo, Javier, Culpa contractual, Temis, Bogotá, 1990, pág. 151.

12 Alessandri Rodríguez, ob. cit., $\mathrm{n}^{\circ} 1472$, pág. 328. De la misma forma lo sostiene en la doctrina actual: DE LA MAZA GaZmuri, "A propósito del artículo 1861”, cit., pág. 460.

13 Así: Corte Suprema, 25 de julio de 2007, Rol 6658 - 2005, nº Legal Publishing: 36814, a propósito de un caso en que se demandó la rebaja de precio e indemnización de perjuicios consistentes en problemas mecánicos y mal funcionaiento de un vehículo, se consideró que la vendedora dado su amplio conocimiento y experiencia debía saber de la existencia del vicio de la cosa vendida. Corte de Apelaciones de Rancagua, 21 de enero de 2008, Rol 828 - 2007, $\mathrm{n}^{\circ}$ Legal Publishing: 38231. En este fallo de forma explícita se señaló que por el oficio desempeñado por la demandada que era una empresa dedicada a la venta de vehículos se puede presumir el conocimiento del vicio según el artículo 1861, presunción que en el proceso no se desvirtuó.

14 Así: Corte Suprema de Justicia, Sala de Casación Civil, 13 de junio de 1946, M.P. Manuel José Vargas, G.J., t. LX, pág. 695. Este caso se refirió a una acción redhibitoria interpuesta por el comprador de un motor de un vehículo estimando que era nuevo y que presentó fallas al ser usado. El fallo de primera instancia declaró rescindido el contrato y decretó las restituciones correspondientes. En apelación se condenó al vendedor a indemnizar perjuicios al comprador 
que el comprador deba probar la culpa del vendedor, y por tanto puede inferirse que la prueba exigida corresponde solamente con demostrar que se trata de un profesional de la actividad relacionada con el bien, ante lo cual los jueces presumen el conocimiento de los mismos y decretan la indemnización.

Se considera que con base en la regla del Código Civil consignada en el artículo 1459 C.C. chil.; 1516 C.C. col.; según la cual el dolo debe probarse salvo en los casos en los que la ley lo presuma, al comprador le corresponde demostrar la conducta dolosa del vendedor que conocía el vicio y no lo declaró. En este punto surge la inquietud consistente en determinar si igualmente tratándose de culpa grave del vendedor profesional, por su asimilación al dolo establecida en los artículos 44 C.C. chil.; y 63 C.C. col., ésta también debe probarse, o si por el contrario, dicha situación está amparada con la presunción de culpa que conforme al artículo 1547 inc. 3 C.C. chil.; 1604 inc. 3 C. C. col. pesa sobre quienes incumplen obligaciones contractuales ${ }^{15}$.

Sobre este interrogante, la interpretación tradicional y generalizada adoptada por los autores chilenos y colombianos, ha consistido en afirmar que la asimilación de la culpa grave al dolo es sólo para los efectos producidos por éste, como son: a) agravación de la responsabilidad, dado que imputándose dolo al deudor, éste responde tanto de los perjuicios que se previeron o pudieron preverse al tiempo del contrato como

lo cual fue confirmado en casación. La Corte Suprema, en sus consideraciones señaló que la vendedora estaba en capacidad para saber si la cosa vendida era nueva o usada pues se dedicaba a la actividad de venta de repuestos de automóviles y por ello ha debido conocer el estado de la cosa vendida. En el mismo sentido: Corte Suprema de Justicia, Sala de Casación Civil, 12 de agosto de 1988, M.P. Héctor Marín Naranjo, G.J., t. CXII, n 2431; Corte Suprema de Justicia, Sala de Casación Civil, 11 de septiembre de 1991, M.P. Alberto Ospina Botero, G.J., t. CCXIII, n² 2451, pág. 120; Corte Suprema de Justicia, 19 de octubre de 2009, cit.

15 Según se ha interpretado en la doctrina colombiana y chilena, dicha norma significa que cuando el acreedor interpone una acción indemnizatoria por inejecución de una obligación contractual, solamente debe probar la existencia de la misma y su incumplimiento, el daño y la constitución en mora del deudor, pero no su culpa, toda vez que ésta se presume, correspondiéndole a éste la prueba sobre su diligencia o la ocurrencia de un caso fortuito. Cfr. OSPINA Fernández, Guillermo, Régimen general de las obligaciones, $7^{\mathrm{a}}$ edición, Temis, Bogotá, 2001, pág. 104. Claro Solar, Luis, Explicaciones de Derecho Civil chileno y comparado, tomo 11, De las obligaciones, II, Imprenta Nascimento, Santiago, 1937, pág. 524. Meza Barros, Ramón, Manual de Derecho Civil. De las obligaciones, $8^{\text {a }}$ edición, Editorial Jurídica de Chile, Santiago, 1990, n⿳0 354, pág. 256 y n 366, pág. 264. Vodanovic H., Antonio, Tratado de las obligaciones, v. II, basado en las explicaciones de Arturo Alessandri y Manuel Somarriva, $2^{\mathrm{a}}$ edición, Editorial Jurídica de Chile, Santiago, 2004, nº 825, pág. 264 y no 844, pág. 276. 
de los que no pudiendo preverse, son consecuencia directa del incumplimiento, según dispone el artículo 1558 C.C. chil.; 1616 C.C. col.; b) el dolo futuro, y por ende la culpa grave, no pueden condonarse, tal como dispone el artículo 1465 C.C. chil.; 1522 C.C. col. Dentro de estos efectos, dicen algunos autores, no se incluye la prueba, de manera que el acreedor está eximido de demostrar la culpa según el ya citado artículo 1547 C.C. chil.; 1604 C.C. col., pero sí le corresponde probar el dolo dado según lo establecido en el artículo 1459 C.C. chil.; 1516 C.C. col. ${ }^{16}$.

Otro sector de la doctrina, por el contrario, considera que la asimilación entre la culpa grave y el dolo es para todas las consecuencias de ello derivadas y así tratándose de culpa grave, el acreedor deberá probar que el deudor incurrió en ella en el incumplimiento de las obligaciones contractuales para obtener la indemnización de perjuicios ${ }^{17}$.

En cuanto a la culpa del vendedor profesional, se puede afirmar que por el contrario, en este caso se presume y el comprador no tiene la carga de probar que el vendedor conocía o debía conocer la existencia del defecto. Es posible plantear que la norma consagra una presunción de culpa sobre el vendedor profesional que debió conocer el vicio en razón de su profesión u oficio, y por tanto el comprador está exonerado de probar la culpa en que incurrió al no examinar el bien y más bien es al vendedor a quien corresponde demostrar la diligencia o cuidado de ello derivada y que podría haberlo conducido a identificar el vicio. No se puede predicar que el vendedor pueda ampararse en la equiparación de la culpa grave al dolo para efectos de asumir que sobre él no pesa la presunción de culpa por incumplimiento de sus obligaciones, pues en este caso la culpa de la que responden tanto el vendedor como el comprador por

16 En este sentido: Cfr. Claro Solar, ob. cit., págs. pág. 525 a 529. Fueyo Laneri, Fernando, Cumplimiento e incumplimiento de las obligaciones, $3^{\text {a }}$ edición actualizada por el profesor Gonzalo Figueroa-Yáñez, Editorial Jurídica de Chile, Santiago, 2004, págs 436 a 437. MEzA BArros, ob. cit., págs. 266 a 267. De la misma forma en la doctrina colombiana: CuBIDES CAMacho, Jorge, Obligaciones, $7^{\mathrm{a}}$ edición, Pontificia Universidad Javeriana - Ibañez, Bogotá, 2012, pág pág. 269. Ospina Fernández, ob. cit., pág. 105.

17 En este sentido BANFi DEL Río, CRISTIÁn, "La asimilación de la culpa grave al dolo en la responsabilidad contractual en Chile", en Revista chilena de Derecho, vol. 27, $\mathrm{n}^{\circ}$ 2, (2000), pág. 329. Igualmente BANFI DEL Río, CRISTIÁN, La asimilación de la culpa grave al dolo en la responsabilidad contractual, Lexis Nexis, Santiago, 2003, págs. 226 a 229. 
el incumplimiento de sus obligaciones, es la leve según la regla consignada en el artículo 1547 C.C. chil.;1604 C.C. col., la que por ello no entra dentro de la asimilación para los efectos que interesan en este trabajo ${ }^{18}$.

\section{Componentes de la indemnización}

Otro aspecto de la indemnización en materia de vicios ocultos, consiste en determinar cuáles son los componentes de la misma. En Colombia Rodríguez Fonnegra afirmó que tratándose de la acción redhibitoria, la indemnización comprende los perjuicios consistentes en el aniquilamiento del contrato, es decir: lo que valdría el bien libre de vicios. En la de rebaja de precio, la indemnización comprendería los que no alcancen a ser indemnizados mediante la rebaja del precio ${ }^{19}$. Se puede afirmar que esta interpretación desconoce el texto normativo, en el cual expresamente se señala que en los eventos aludidos, el vendedor "...será obligado no sólo a la restitución o a la rebaja del precio, sino a la indemnización de perjuicios", lo cual evidencia que no son iguales y por tanto cabe ser leído así: en los casos mencionados, el comprador tendrá derecho a la restitución o a la rebaja del precio, además de la indemnización de perjuicios ${ }^{20}$.

18 En contra, Banfi del Río, quien señala que la culpa a la cual se refiere el artículo 1861 C.C. chil., (1918 C.C. col.), es grave. BANFI DEL Río, "La asimilación de la culpa grave al dolo en la responsabilidad contractual en Chile", cit., pág. 328 y BANFI DEL Río, La asimilación de la culpa grave al dolo en la responsabilidad contractual, cit., pág. 247. A mayor abundamiento, se puede afirmar que la exoneración de la prueba de la culpa del deudor, solamente tiene cabida en cuanto a aquella de la que debe responder. En este caso, dado que las partes del contrato de compraventa responden por culpa leve en el cumplimiento de sus obligaciones, la presunción que asume por el incumplimiento recae sobre ésta, pero si el acreedor considera que debe ser llamado a responder sea por la culpa grave o quisiera pedir la aplicación de los efectos propios de su equiparación al dolo, debería probar que fue ésta la culpa en que incurrió el vendedor. En este sentido en la doctrina chilena: Abeliuk Manasevich, René, Las obligaciones, tomo II, $5^{\text {a }}$ edición, Editorial Jurídica de Chile, Santiago, 2008, pág. 825. En la colombiana: OspinA FERnÁNDEZ, ob. cit., pág. 105.

19 Rodríguez Fonnegra, Jaime, De la compraventa y materias aledañas, Lerner, Bogotá, 1960, pág. 905.

20 En el Código Civil chileno - colombiano, no se reproduce lo que sí en el artículo 1486 (II) del Código Civil español, según el cual sólo se reconoce la posibilidad de reclamar indemnización si se opta por la rescisión y no por la rebaja de precio. Algunos autores, al explicar esta norma, señalan que en la rebaja de precio no hay lugar a pedir indemnización, pues ya para dicha rebaja se ha tenido en cuenta el perjuicio del comprador. Así: CASTÁn ToBeÑAs, José, Derecho Civil español común y foral, t. 4, Derecho de obligaciones, las particulares relaciones 
Pérez Vives afirmó, aunque sin dejar claro con qué argumentos, que la indemnización comprende el daño emergente y el lucro cesante ${ }^{21}$. En el mismo sentido en Chile Alessandri Rodríguez, argumentando que al no establecer la norma el tipo de perjuicios debidos, debe acudirse a las reglas generales de los artículos 1556 y 1558 C.C. chil. (1613 y 1616 C.C. col.), de las cuales se deduce que el vendedor debe indemnizar el daño emergente y el lucro cesante y "...si hubo dolo de su parte no solamente los perjuicios que se previeron o pudieron preverse al tiempo del contrato sino todos aquéllos que fueron una consecuencia inmediata o directa de la inejecución de su obligación" 22 .

Conforme a lo planteado anteriormente en relación a que en el artículo 1861 C.C. chil.; 1918 C.C. col., se consagran dos eventos que son la responsabilidad por dolo del vendedor que conocía los vicios y no obstante no los declaró y por culpa, que corresponde a la del vendedor profesional que debió haber conocido tales vicios, parece que es la propuesta de Alessandri Rodríguez la correcta y con base a ella, deberán hacer las distinciones del artículo 1558 C.C. chil.; 1616 C.C. col.

En la jurisprudencia colombiana, un fallo de la Corte Suprema de Justicia de 19 de octubre de 2009 ya aludido, consideró

obligatorias, 15ª edición, Reus, Madrid, 1993, pág. 134 y BADENes GASSET, RAmón, El contrato de compraventa, tomo 1, 3a edición, José María Bosch editor, Barcelona, 1995, pág. 662. Según LlÁcer MataCÁs no resulta lógico que el comprador que opta por la rebaja de precio pueda pedir además indemnización, argumentando así: para que ésta proceda, además del dolo del vendedor se requiere la existencia de daños en los bienes del comprador los que sólo se pueden resarcir o por medio de la indemnización sóla o por la acción redhibitoria más indemnización. LláCER MATACÁs, ob. cit., pág. 1518. De forma contraria se puede asumir que la indemnización sólo tiene cabida cuando por los vicios se causan daños a otros bienes del comprador. Esto, aunque puede suceder y así se verá, no es requisito para la procedencia de la indemnización a la que tales normas se refieren. Se trata del daño generado para el comprador al no permitirle obtener la utilidad esperada por el bien y no los daños ocasionados en otros bienes o incluso en la persona misma del deudor. Además, no se ve razón para no permitir la indemnización al daño producido por una expectativa contractual frustrada o de no poder utilizar el bien durante un tiempo, independientemente de que el contrato se mantenga con la rebaja de precio. Sobre la posibilidad de admitir la compatibilidad de la acción estimatoria y la indemnizatoria, salvo cuando se trate de indemnizar el perjuicio consistente en el menor valor que la cosa vendida tiene a causa del vicio: Verda y BeAmonte, ob. cit., págs. 305 a 306. Cabe agregar, que en la Propuesta de Modernización del Código Civil en materia de obligaciones y contratos, en España, la acción indemnizatoria a la que tiene derecho el acreedor por los daños y perjuicios causados por el incumplimiento, es compatible con las demás acciones reconocidas en caso de inejecución, tal como se establece en el artículo 1205.

21 Pérez Vives, ob. cit., nº 343, pág. 382.

22 Alessandri Rodríguez, ob. cit., nº 1469, pág. 325. 
también que la acción indemnizatoria comprende el daño emergente y el lucro cesante. En este fallo, la Corte Suprema tampoco se descarta la indemnización de perjuicios derivados de “... la obligación del vendedor de entregar cosa en el estado que garantice el aprovechamiento y la utilidad que la naturaleza de ella indique", de forma que el comprador podría intentar una indemnización compensatoria "... que comprenda todo el daño emergente y todo el lucro cesante sufridos por él como consecuencia de la inejecución absoluta o imperfecta de la obligación..."23.

En la jurisprudencia chilena, un fallo reciente de la Corte Suprema ha considerado que la indemnización de perjuicios por vicios redhibitorios generados por concurrir culpa grave o dolo incluye los daños "...tanto de la naturaleza de la indemnización (compensatoria y moratoria), como de la extensión de los daños y perjuicios (material y moral; daño emergente y lucro cesante; perjuicios previstos e imprevistos; directos e indirectos...)"24.

Como ya se manifestó, la responsabilidad por vicios en caso de mala fe del vendedor constituye un evento de responsabilidad por violación dolosa o culposa de un deber de información, por lo que tiene naturaleza precontractual y debe comprender el interés positivo al cumplimiento de la obligación de entregar una cosa sin vicios incluyendo el daño emergente y el lucro cesante. Además, en caso de dolo, el vendedor estará obligado a indemnizar todos los daños directos que sean consecuencia inmediata o directa del incumplimiento de su deber de informar, previsibles e imprevisibles, conforme al artículo 1558 C.C. chil; 1616 C.C. col. $^{25}$.

23 Corte Suprema de Justicia, 19 de octubre de 2009, cit.

24 Corte Suprema, 27 de marzo de 2008, Rol 6700 - 06, Microiuris.

25 En la doctrina colombiana se ha dicho que las reglas sobre responsabilidad contractual del Código Civil no excluyen la reparación del daño moral. Cfr. Cubides CAmacho, ob. cit., págs. 311 a 314. Ospina FernándeZ, ob. cit., págs. 118 a 121. Igualmente en Chile: RodrígueZ Grez, Pablo, Responsabilidad contractual, Editorial Jurídica de Chile, Santiago, 2003, pág. 237. Por su parte, Corral Talciani sugiere que debe juzgarse caso por caso según la regla de la previsibilidad. Corral Talciani, Hernán, Contratos y daños por incumplimiento, Abeledo Perrot - Legal Publishing, Santiago, 2010, pág. 198. 


\section{RESPONSABILIDAD POR DAÑOS OCASIONADOS POR LA COSA VICIOSA}

Como se surigió en la introducción a este trabajo, cabe preguntarse si la indemnización de perjuicios a la que se refieren los artículos citados incluyen la responsabilidad por daños ocasionados por la cosa viciosa a la persona o bienes del comprador o a terceros. Esto, pues el Código no es claro en señalar si los incluye. Se hará referencia a continuación a las soluciones que han sido adoptadas en el Derecho comparado y posteriormente a las posibilidades existentes en el Derecho Civil chileno - colombiano.

\section{A. La solución adoptada por el Derecho italiano, francés y alemán}

A diferencia de lo que sucede en el Código chileno - colombiano y en otras codificaciones similares, el Código Civil italiano contiene una disposición que obliga al vendedor a resarcir además los daños derivados de los vicios de la cosa, que es la establecida en el inciso segundo del artículo 1494. En esta codificación, conforme a la interpretación prevalente, mientras la primera parte de esta norma se refiere al resarcimiento del daño directo, como el menor valor de la cosa, los gastos de reparación, el no haber podido usar el bien temporalmente, el lucro cesante, la pérdida de clientela y similares, la segunda parte alude a daños indirectos o ulteriores provocados por la cosa viciada a la persona del comprador, a otros bienes del mismo o a terceros, como pudieran ser lesiones personales, de manera que la norma consagra una responsabilidad aquiliana fundada en poner en circulación un producto peligroso que puede hacerse valer ya sea por el comprador como por cualquier tercero perjudicado con el producto defectuoso, que por su carácter extracontractual se sustrae del régimen de prescripción del artículo 1495 del Código italiano ${ }^{26}$.

26 Luminoso, Angelo, La compravendita, sesta edizione, Giappichelli, Torino, 2009, pág. 294. Rubino, Domenico, La compravendita, en Trattato di Diritto Civile e Commerciale diretto dai professori Antonio Cicu; Francesco Messineo, vol., XXIII, Giuffrè, Milano, 1971, pág. 823. Igualmente Bianca, quien reconoce que en el artículo 1494 del Codice, hay una responsabilidad 
En el Derecho francés también se ha asumido desde hace tiempo que la indemnización a la que está obligado el vendedor de mala fe y a la que se refiere el artículo 1645 del Code incluye los daños derivados del contrato: el daño emergente y el lucro cesante $^{27}$. Tanto la doctrina como la jurisprudencia han hecho esfuerzos por encontrar otro mecanismo para sancionar la entrega de una cosa defectuosa en virtud del contrato de venta. Así, la jurisprudencia francesa desarrolló una "obligación de seguridad", sancionando su inobservancia con las reglas de responsabilidad del derecho común y ha llegado a admitir que al vendedor profesional se le presume el conocimiento de los vicios para obligarlo a indemnizarlos según el artículo 1645, abarcando tanto el daño originado por la compraventa ("perjuicio comercial"), como el ocasionado a un bien jurídicamente tutelado ("perjuicio causado por la cosa") 28 .

También en el Derecho alemán, conforme al $\S 463$ original del BGB, sólo cabía pedir la indemnización de perjuicios si la cosa objeto del contrato no tenía una cualidad prometida o si el vendedor había ocultado el defecto de forma fraudulenta. Frente a la pregunta sobre la responsabilidad del vendedor por los daños causados por la cosa, Zimmermann hace un recuento del esfuerzo de los tribunales alemanes por extender la responsabilidad, lo que se logró aplicando normas sobre la infracción del contrato, pero limitándola a la pretensión de indemnización de los daños ocasionados en otros bienes del comprador, diferentes de los generados en el bien defectuoso ${ }^{29}$. La reforma del 2002, ha consagrado en el $\S 437$ como uno de los derechos del

contractual (primera parte) y extracontractual (segunda parte). Bianca, Cesare Massimo, $L a$ vendita e la permuta, en Trattato di Diritto Civile Italiano fondato da Filipo Vassalli, vol. 7, t. 1, seconda edizione, Utet, Torino, 1993, págs. 984 a 990. Cabella Pisu, LuCiana, La reticenza nella formazione del contratti, Cedam, Padova, 1972, pág. 186. VISINTINI, ob. cit., págs. 186 a 187. Como señala Luminoso, esta no es necesariamente la responsabilidad del productor de bienes defectuosos. Luminoso, ob. cit., pág. 295.

27 Mazeaud, Henri, "La responsabilité civile du vendeur-fabricant", en RTD Civ., t. Cinquante - troisième, (1955), $n^{\circ} 10$, pág. 613.

28 Mazeaud, ob. cit., núms. 4 a 6, págs. 612 a 613. Bénabent, Alain, Droit Civil. Les contrats spéciaux civils et commerciaux, 9e édition, Montcherestien Lextenso éditions, Paris, 2011, $\mathrm{n}^{\circ}$ 369, pág. 170. Borghetti, JeAn - Sébastien, La responsabilité du fait es produts. Étude de droit comparé, L.G.D.J., Paris, 2004, págs. 204 a 207 y 217 a 224. FAURe ABbaD, ob. cit., nº 547, págs. 443 a 444. HuEt, ob. cit., núms. 11376 y 11377, págs. 324 a 327.

29 Zimmermann, Reinhard, The New German Law of Obligations, Oxford University Press, Oxford, 2005, pág. 92. 
comprador por vicios, el derecho a reclamar el resarcimiento del daño o el reembolso de los gastos infructuosos, sin limitarlo a eventos de conocimiento o no del vendedor, según los $\S \S 280$, 281 y 283, que incluye el resarcimiento del daño por violación de un deber de la relación obligatoria; el resarcimiento en lugar de la prestación, o los daños simples, como podría ser el caso de los daños ocasionados a otros bienes del comprador ${ }^{30}$.

\section{B. La solución propuesta para el Derecho chileno y colombiano}

Los primeros autores en la doctrina chilena y colombiana que se refirieron a la inclusión o no dentro de la responsabilidad por vicios ocultos, de los daños generados a otros bienes del comprador, señalaron que la indemnización a la cual es obligado el vendedor en los eventos ya mencionados comprende los daños ocasionados por la cosa viciosa a los demás bienes. Así para Alessandri Rodríguez dentro de los valores que debe abonar el vendedor se encuentran los daños que la cosa haya generado a los demás bienes ${ }^{31}$. Igualmente ha sido la opinión en Colombia de Rodríguez Fonnegra ${ }^{32}$.

Al contrario de estas autorizadas opiniones, se considera que en estos casos deberá acudirse a las reglas genéricas de responsabilidad, y por tanto puede afirmarse la existencia de dos regímenes de indemnización: uno, corresponde a los daños ocasionados al comprador por la falta del deber de información y relacionados con la falta de calidad o idoneidad que compromete el uso natural o pactado, ya aludidos, y el otro el de

30 Zimmermann, ob. cit. págs. 108 a 112. Markesinis, Basil B.; Unberath, Hannes; Johnston, Angus, The German Law of Contract. A Comparative Treatise, 2nd edition, Hart Publishing, Oregon, 2006, págs. 438 a 464 y 469 a 471. De igual manera, en España, el derecho a exigir la indemnización por incumplimiento, en la propuesta de modernización del Código Civil en materia de obligaciones y contratos, tal como se encuentra en el artículo 1190, no depende del conocimiento o no del defecto por el vendedor. Con todo, según el artículo 1208 de la propuesta, el deudor responde de los daños y perjuicios objetivamente imputables a su incumplimiento y si éste no hubiera sido doloso, sólo responderá de los daños que se hubiesen previsto o podido prever razonablemente como consecuencia probable de la falta de cumplimiento de la celebración del contrato. Esta regla, guarda equivalencia con la establecida en el Código Civil chileno - colombiano. Cfr. Artículo 1558 C.C. chil.; 1616 C.C. col.

31 Alessandri Rodríguez, ob. cit., nº 1469, pág. 325.

32 Rodríguez Fonnegra, ob. cit., pág. 905. 
daños causados por la cosa, regido por las reglas generales de responsabilidad y que no tiene razón para encontrarse también limitado a los casos en que el vendedor los conociere o fuese un profesional ${ }^{33}$. Además, el supuesto del daño ocasionado por el vicio no necesariamente coincide con el del defecto que causa daños al comprador, a terceros o a sus bienes, que se acerca más al de "peligrosidad", como se ha entendido en otros ámbitos de manera que ya no se estaría hablando de la responsabilidad contractual por vicios ocultos ${ }^{34}$.

Se comparte esta última posibilidad, de forma que puede afirmarse que tratándose de vicios redhibitorios, existe una indemnización diferente de la derivada de la culpa o dolo en que incurra el vendedor por no informar sobre la existencia de los vicios, sino también una indemnización de carácter compensatorio a favor del comprador por los daños ocasionados por los defectos del bien, la que se rige por las reglas generales y no por las reglas de indemnización edilicias ${ }^{35}$. Sobre la responsabilidad para con los terceros a causa de los vicios, aunque tal vez resulta obvio, se puede considerar que al operar la indemnización por vicios ocultos sólo entre las partes del contrato, a dichos terceros les corresponde acudir a las reglas generales existentes en el Código Civil para lograr una indemnización conforme por la vía de la responsabilidad civil extracontractual ${ }^{36}$.

33 En su momento Rojo y Fernández - Rio, Ángel, La responsabilidad civil del fabricante, Publicaciones del Real Colegio de España, Bolonia, 1974, págs. 244 a 245.

34 En este sentido Corral Talciani afirma que el vicio oculto parece estar centrado en la falta de calidad del producto más que en su peligrosidad. Corral TalCiani, Hernán, Responsabilidad por productos defectuosos. Análisis y propuestas para el Derecho Civil y de consumo en Chile, Abeledo Perrot - Legal Publishing, Santiago, 2011, pág. 93.

35 Según Corral Talciani, en la doctrina chilena, el afectado por un producto dañino a causa de los defectos podrá accionar conforme a los artículos 2314 y siguientes del Código Civil chileno. Corral Talciani, Responsabilidad por productos defectuosos, cit., págs. 99 a 107. Estas normas equivalen al artículo 2341 y siguientes del Código Civil colombiano. Parece orientarse la doctrina mayoritaria a pensar que es el artículo 2329 C.C. chil.; 2356 C.C. col., la base de esta responsabilidad. En este sentido en Chile: BArros Bourie, ob. cit., pág. 751 y en Colombia: Tamayo Jaramillo, Javier, Tratado de responsabilidad civil, tomo 1, $2^{\mathrm{a}}$ edición, Legis, Bogotá, 2007, pág. 1045. Señala Corral Talciani, en opinión compartida, al tratarse de un régimen de culpa presunta, sería admisible la exoneración de responsabilidad si se acredita que el defecto se produjo a pesar de las cautelas y medidas de seguridad exigibles. En todo caso, el autor expresa sus dudas sobre que esta norma consagre una presunción de culpa por hecho propio sino que es la expresión de una exigencia de la relación causal. CORRAL TALCIANI, Responsabilidad por productos defectuosos, cit., págs. 101 a 103.

36 En la doctrina chilena, con comentarios que caben también para el Derecho colombiano, 


\section{El CARÁCter PRincipal o ACCESORIO DE LA INDEMNIZACIÓN}

Como se ha señalado anteriormente, tampoco existe claridad normativa acerca del carácter principal de la acción indemnizatoria o accesorio de la acción redhibitoria o de rebaja de precio. A continuación se analizarán las tendencias del Derecho comparado al igual que la posición de la doctrina y jurisprudencia de Chile y Colombia.

\section{A. La tendencia en el Derecho comparado}

Tratándose de vicios ocultos, en el Derecho comparado se puede observar una tendencia uniforme a aceptar la independencia de la acción de indemnización en relación con las acciones edilicias. De esta manera, en Italia Luminoso sugiere la posibilidad para el comprador de demandar la indemnización con independencia de la acción redhibitoria o estimatoria ${ }^{37}$. Indica Mastrorilli que en el Derecho italiano se ha asumido tradicionalmente por la jurisprudencia la autonomía de la acción resarcitoria respecto a las acciones derivadas de la garantía, tal como lo señala la sentencia de casación de 7 de marzo de 2007 citada por la autora, en la cual se dispuso que la acción de resarcimiento del daño propuesta en el sentido del artículo

\footnotetext{
Corral Talciani se ha pronunciado sobre la insuficiencia del régimen de vicios ocultos para la reparación de daños por productos fabricados sin la seguridad necesaria, especialmente enfocada a las relaciones de consumo, posición que se pueden resumir así: 1) la responsabilidad contractual ha sido concebida para operar dentro del marco del contrato, de forma que la víctima estaría excluida de dicho régimen si no fuere el comprador; 2) el régimen de responsabilidad por vicios ocultos no cubre los daños producidos en la persona del comprador o en otros bienes de su patrimonio distinto al vendido; 3) la responsabilidad contractual, al exigir que los vicios sean ocultos supone una relación bilateral en igualdad de condiciones, la que no se presenta en relaciones de consumo pues al adquirente no se le puede exigir que examine detenidamente los bienes para constatar la no presencia de defectos; 4) la responsabilidad por vicios ocultos puede ser limitada o excluida mediante cláusulas de exoneración y 5) las acciones por vicios ocultos, prescriben o caducan en corto tiempo. CorRal TALCIANI, Responsabilidad por productos defectuosos, cit., págs. 13 a 14. Sobre la última de las observaciones planteadas por el autor, corresponde anotar que como se sostiene en este trabajo, cabe predicar la independencia de la acción de indemnización a causa de los vicios de las edilicias, por lo cual los términos de prescripción no son los mismos.

37 Luminoso, ob. cit., pág. 293. Igualmente Terranova, Carlo, "La garanzia per vizi e difetti di qualità della cosa venduta", en I Contratti di Vendita, tomo secondo, a cura di Daniela Valentino, Trattato dei contratti, diretto da Pietro Rescigno ed Enrico Gabrielli, Utet, Torino, 2007, pág. 1139.
} 
1494 C.C., del adquiente, no se identifica ni con la acción de garantía del artículo 1492 C.C., ni con la acción de exacto cumplimiento, y por tanto la acción de resarcimiento del daño que presupone la culpa del vendedor, consistente en la omisión de la diligencia necesaria para descubrir la eventual presencia del vicio en la cosa, puede extenderse a todos los daños generados al adquirente, no solo aquellos relativos a los actos necesarios para la eliminación del vicio, sino también a los inherentes a la falta o parcial utilización del bien o al lucro cesante, de manera que el comprador la puede interponer de forma alternativa o acumulándola con la acción de cumplimiento específico del contrato, de reducción del precio o de resolución. Aunque como también indica la autora, se ha entendido por la jurisprudencia, sometida a la prescripcción de las acciones por vicios, como en la sentencia de casación de 8 de mayo de $2005^{38}$.

También en el Derecho francés se ha asumido que el comprador víctima de un vicio redhibitorio puede obtener una indemnización independientemente o en complemento de la acción redhibitoria o de la estimatoria, en los casos en que el vendedor conocía los vicios, basándose en el artículo 1645 del Code ${ }^{39}$.

Según plantea en España Pantaleón, en los remedios indemnizatorios debe diferenciarse la responsabilidad contractual en sentido estricto, condicionada a que el incumplimiento dañoso sea imputable al deudor de la indemnización de los gastos del contrato, aunque la ignorancia de la circunstancia que lleva a la resolución no sea imputable a él ${ }^{40}$. Ahora, aunque en España un autor ha sostenido que la acción de indemnización por los vicios es acesoria o complementaria de las acciones edilicias ${ }^{41}$, en la doctrina reciente, Diez - Picazo sostiene que aunque el

38 Mastrorilli, Annachiara, La garanzia per vizi nella vendita. Disciplina del codice civile e del codice di consumo, seconda edizione, Giuffrè, Milano, 2009, págs. 191 a 192.

39 Collart Dutilleul, François; Delebecque, Philippe, Contrats civils et commerciaux, $8^{\mathrm{e}}$ édition, Dalloz, Paris, 2007, nº 289, pág. 249. Los autores hacen referencia a fallos que así lo han decidido.

40 Pantaleón Prieto, Fernando, "Las nuevas bases de la responsabilidad contractual", en Anuario de Derecho Civil, t. XLVI, f. IV, (1993), cit., pág. 1727.

41 En este sentido: Orti Vallejo, Antonio, La protección del comprador por el defecto de la cosa vendida, Ediciones TAT, Granada, 1987, pág. 420 y Orti Vallejo, Antonio, Los defectos de la cosa en la compraventa civil y mercantil, Comares, Granada, 2002, pág. 202. 
párrafo segundo del artículo 1486 del Código Civil establece la acción indemnizatoria cuando el vendedor los conociera y no los hubiere manifestado y además el comprador opte por la rescisión, excluyéndola para el caso de ejercicio de la acción de rebaja de precio, acepta que la acción indemnizatoria puede ejercitarse de manera independiente de dichas acciones y sin necesidad de haber optado entre ellas ${ }^{42}$. También cabe tener en cuenta que en Alemania, el derecho a reclamar perjuicios no depende del ejercicio o no de otros derechos por parte del comprador, según se deriva del § 437, tras la reforma de 2002.

Por otra parte, en los instrumentos internacionales de contratación también se reconoce la naturaleza autónoma de la acción indemnizatoria, en los que a partir de la obligación de conformidad asumida por el vendedor, le atribuyen responsabilidad contractual en caso de no satisfacción del interés del comprador referido a la obtención de la utilidad esperada, cuando se verifique una situación de falta de conformidad.

En la Convención de las Naciones Unidas sobre los Contratos de Compraventa Internacional de Mercaderías, adoptada en Colombia por Ley 518 de 1999, la obligación de conformidad material, regulada a partir del artículo 35, puede ser entendida como el compromiso asumido por el vendedor para con el comprador consistente en que la cosa entregada corresponda en cuanto a su cantidad, calidad y tipo a la pactada, además que resulte útil ya sea para el uso ordinario al que se dedique mercaderías del mismo tipo o para el uso especial que expresa o tácitamente se haya hecho saber al vendedor al momento de celebración del contrato. La falta de conformidad se establece como una situación de incumplimiento que da lugar a los remedios generales por ella consagrados (artículos 45 y 46) ${ }^{43}$. Puede advertirse que algunos de estos remedios tienen naturaleza resolutoria, tales como la rebaja de precio o la resolución

42 Díez - Picazo, ob. cit., págs. 141 a 142.

43 Morales Moreno, Antonio MAnuel, "Tres modelos de vinculación del vendedor en las cualidades de la cosa", en Anuario de Derecho Civil, t. LXV, f. I, (2012), pág. 19. Recuérdese que la Convención adopta un sistema unitario de incumplimiento y de remedios. Morales Moreno, Antonio Manuel, "Autonomía de la voluntad y responsabilidad en la Convención de Viena sobre compraventa internacional de mercaderías", en La modernización del Derecho de obligaciones, Antonio Manuel Morales Moreno, Thomson Civitas, Cizur Menor, 2006, pág. 212. 
por incumplimiento esencial, mientras otros son formas de cumplimiento forzado: la reparación o sustitución ${ }^{44}$.

Adicionalmente, el afectado con la falta de conformidad tiene derecho a buscar una indemnización por los daños derivados de tal situación, según lo dispone el artículo 45 numeral $1^{\circ}$ literal $b$, independientemente de haber acudido a cualquiera de los remedios del acreedor frente al incumplimiento del deudor. Los artículos 45 numeral $1^{\circ}$ literal b y 61 numeral $1^{\circ}$ literal $b$, así lo establecen y de la misma forma se ha reconocido en la doctrina, al señalar que tal remedio puede intentarse bien sea combinada con otra acción por incumplimiento, apoyándose para ello en el artículo 45 (2) de la Convención, o de forma independiente ${ }^{45}$.

Siguiendo esta tendencia, también de forma expresa el artículo 7.4.1 de los Principios de Unidroit sobre los Contratos Comerciales Internacionales reconoce el derecho a obtener una indemnización por incumplimiento de las obligaciones de forma autónoma o en concurrencia con otras acciones.

\section{B. La cuestión en la doctrina y jurisprudencia de Chile y Colombia}

Tanto en materia de responsabilidad por incumplimiento como en relación con la indemnización especial por vicios ocultos, tanto en Chile como en Colombia, las posiciones doctrinales sobre la independencia de la indemnización no son pacíficas.

Para Alessandri Rodríguez en la doctrina chilena, la indemnización forma parte del saneamiento, por lo que la acción redhibitoria o la de rebaja de precio la comprenden cuando

44 Morales Moreno, "Tres modelos...”, cit., pág. 20. Una explicación detallada sobre los remedios que conforman el sistema de protección al comprador ante la falta de conformidad en la Convención, puede verse en: Vidal Olivares, Álvaro, La protección del comprador. Régimen de la Convención de Viena y su contraste con el Código Civil, Ediciones Universitarias de Valparaíso, Pontificia Universidad Católica de Valparaíso, Valparaíso, 2006, págs. 53 a 165.

45 Cfr. Audit, Bernard, La compraventa internacional de mercaderías. Convención de las Naciones Unidas del 11 de abril de 1980, traducción de Ricardo de Zavalía, Zavalía, Buenos Aires, 1994, pág. 196. Müller - Chen, Markus, "Article 45", en Commentary on the UN Convention on the international sale of goods (CISG), Schlechtriem; Schwenzer / Ingeborg Schwenzer (ed.), $3^{\text {rd }}$ ed., Oxford University Press, Oxford, 2010, págs. 690 y 699. Plitz, Bughard, Compraventa internacional. Convención de Viena sobre Compraventa Internacional de Mercaderías de 1980, Astrea, Buenos Aires, 1998, pág. 118. 
ésta procede ${ }^{46}$. Por esto, el autor consideró que el término de prescripción de la acción indemnizatoria queda sujeto al de las acciones redhibitorias ${ }^{47}$. De forma similar Rodríguez Fonnegra en la doctrina colombiana, quien concluyó que las acciones de indemnización tienen el carácter de "anexas" a las edilicias ${ }^{48}$. Doctrina reciente tanto en Chile como en Colombia ha considerado que la indemnización de perjuicios es diferente y autónoma de las acciones redhibitoria y de rebaja de precio y, como consecuencia de esto se ha afirmado que los términos de prescripción de ellas no comprenden la indemnizatoria, a la cual cabría aplicar los términos generales ${ }^{49}$. En Chile, no hay un criterio definido en la jurisprudencia, aunque últimamente parece optar por considerar que la acción indemnizatoria tie-

46 Alessandri Rodríguez, ob. cit., nº 1508, págs. 363 a 364.

47 Alessandri Rodríguez, ob. cit., nº 1508, pág. 364. Igualmente Díez Duarte, Raúl, La compraventa, $2^{\mathrm{a}}$ edición actualizada por Eric Andrés Chávez Chávez, El Jurista, Santiago, 2009, pág. 261. Parece estar de acuerdo con que el plazo de prescripción de la acción indemnizatoria es el mismo de las edilicias: Corral TALCIANI, Responsabilidad por productos defectuosos, cit., pág. 96.

48 Rodríguez Fonnegra, ob. cit., pág. 909.

49 En este sentido Vidal Olivares, Álvaro, "La indemnización de daños y la opción del acreedor frente al incumplimiento", en Estudios de Derecho Civil VI, Jornadas nacionales de Derecho Civil Olmué, 2010, Gonzálo Figueroa Yáñez; Enrique Barros Bourie; Mauricio Tapia Rodríguez (Coordinadores), Abeledo Perrot - Legal Publishing, Santiago, 2011, pág. 778. de la Maza también afirma el carácter autónomo de la acción indemnizatoria del artículo 1861 C.C. chil. DE la Maza Gazmuri, "A propósito del artículo 1861", cit., pág. 457. Aunque en este trabajo no nos ocupamos de analizar la acción indemnizatoria por incumplimiento contractual, cabe señalar que en Colombia OSPINA FernÁndeZ indica que es posible demandar de forma autónoma la indemnización de perjuicios sin necesariamente ligarla a la acción por incumplimiento contractual. Ospina Fernández, ob. cit., pág. 89. Igualmente Oviedo Albán, Jorge, “Exclusión tácita de la ley aplicable e indemnización de perjuicios por incumplimiento de un contrato de compraventa internacional (a propósito de reciente jurisprudencia chilena”, en International Law. Revista colombiana de Derecho Internacional, 14, (2009), págs. 191 a 219. En la doctrina chilena varios autores conciben que la indemnización por incumplimiento contractual es subsidiaria. Cfr. Abeliuk Manasevich, ob. cit., pág. 811. Fueyo Laneri, ob. cit., págs. 347 a 348. En contra, en la doctrina reciente: Pizarro Wilson se muestra partidario de la postura tendiente a reconocer independencia a la acción de indemnización de perjuicios por incumplimiento del contrato, de manera general. Pizarro Wilson, CARlos, "La responsabilidad contractual en el Derecho chileno", en Los contratos en el Derecho Privado, Fabricio Mantilla-Espinosa; Francisco Ternera-Barrios, (Directores), Universidad del Rosario, Legis, Bogotá, 2007, págs. 209 a 233, esp. 214 a 216. Vidal Olivares, "La indemnización de daños...”, cit., págs. 763 a 779. López Díaz, Patricia Verónica, "La indemnización compensatoria por incumplimiento de los contratos bilaterales como remedio autónomo en el Derecho Civil chileno", en Revista Chilena de Derecho Privado, n 15, (2010), págs. 65 a 113, esp. págs. 85 a 113 y López DíAz, Patricia VERÓNICA, "El interés del deudor como límite al derecho de opción del acreedor insatisfecho y su incidencia en la procedencia de la acción de cumplimiento específico y la indemización de daños", en Estudios de Derecho Civil VII, Jornadas nacionales de Derecho Civil Viña del Mar, 2011, Fabián Elorriaga De Bonis (coordinador), Abeledo Perrot Legal Publishing - Thomson Reuters, Santiago, 2012, pág. 745. 
ne naturaleza autónoma y por ello prescribe según las reglas generales y no conforme a los plazos de las acciones edilicias, aunque otros han predicado lo contrario.

La Corte de Apelaciones de Santiago, en un fallo de 2006 en el que confirmó la sentencia apelada, señaló que la acción de indemnización por vicios redhibitorios tiene plazo de prescripción de corto tiempo, en un caso en el que se demandó la indemnización de perjuicios por vicios ocultos consistentes en los errores de ductos de combustión de un edificio, aduciendo el demandante en apelación que la acción indemnizatoria está sometida a las reglas generales de prescripción previstas en el artículo 2515 C.C. ${ }^{50}$.

En otro fallo, la Corte de Apelaciones de San Miguel, al conocer del recurso de apelación en un caso relativo a una acción de rebaja de precio e indemnización de perjuicios por vicios ocultos, interpuesta por los compradores de unos departamentos contra la vendedora, una empresa constructora, contra el fallo de primera instancia que a pesar de la pretensión de rebaja de precio decretó la resolución del contrato, consideró que la indemnización tiene carácter accesorio a la acción redhibitoria y a la de rebaja de precio, y por ello el término de prescripción no es el general sino el de las acciones especiales, por lo cual afirmó que la acción indemnizatoria estaba prescrita, cuestión alegada por la demandada en su contestación ${ }^{51}$.

En un fallo de 2012, la Corte Suprema asumió también esta postura. El caso se basó en los siguientes hechos: el comprador de unos fertilizantes utilizados en una plantación de papas, demandó al vendedor alegando que éste había incurrido en incumplimiento grave de sus obligaciones y además señaló la presencia de vicios redhibitorios en la cosa vendida, puesto que por la composición corrosiva de los fertilizantes la plan-

50 Corte de Apelaciones de Santiago, 31 de octubre de 2006, Rol 6803-2001, $\mathrm{n}^{\circ}$ Legal Publishing: CL/JUR/3524/2006; J3345/2006.

51 La Corte, decidió la procedencia de la indemnización para uno de los apelantes puesto que era el único a quien no le había prescrito la acción y estableció además que para determinar si ella procedía, debía verificarse si la vendedora conocía o debía conocer los vicios, concluyendo afirmativamente dada la profesión de su representante. Corte de Apelaciones de San Miguel, 27 de enero de 2006, Rol 1605 - 2001, n Lexis Nexis: 35531. La Corte Suprema desestimó la Casación en el fondo. Corte Suprema, 27 de noviembre de 2007, Rol 2265 - 2006, n Legal Publishing: 37855. 
tación se afectó lo cual generó pérdidas, por lo que basándose en el artículo 1860 del Código Civil, pidió obligar al vendedor a indemnizar el daño emergente, lucro cesante y daño moral, reajustes intereses, más costas de la causa, todo lo cual lo tasó en $\$ 141.000 .000$.

El Segundo Juzgado Civil de Puerto Montt mediante sentencia de 20 de septiembre de 2011 rechazó la demanda, decisión que fue confirmada por la Corte de Apelaciones de Puerto Montt en fallo de 18 de junio de 2012. La Corte Suprema rechazó el recurso de casación en el fondo deducido por el demandante contra el fallo de la Corte de Apelaciones, mediante decisión de 28 de noviembre de 2012. En el considerando tercero de la decisión de la Corte Suprema, se resume la posición del Tribunal de Apelaciones en torno al tema disputado por las partes acogida por la Corte, señalando que la acción indemnizatoria interpuesta por el comprador requiere demandar primero cualquiera de las acciones edilicias, las que al estar prescritas en el caso concreto conllevan que la indemnizatoria también lo esté 52 .

En sentido contrario, se encuentra un fallo de la Corte de Santiago referido a una acción indemnizatoria interpuesta de forma independiente. El fallo acogió las pretensiones de una demanda por indemnización de perjuicios basada en la entrega de una edificación en forma defectuosa o imperfecta, como eran los vicios de construcción, conforme a la regla general del artículo 1556 C.C. chil., y no como indemnización accesoria por vicios ocultos. La demanda se basó en una pretensión de indemnización compensatoria por incumplimiento de obligaciones contractuales, toda vez que la entrega de dieciocho departamentos objeto de un contrato de venta se hizo con materiales de construcción e instalaciones deficientes, en especial con defectos en los conductos interiores de suministro de gas. La demandada alegó que la acción de saneamiento por vicios ocultos se encontraba prescrita conforme al artículo 1866 del Código Civil y que el incumplimiento en que pudo haber incurrido el primer vendedor no le era oponible, de conformidad

52 Corte Suprema, 28 de noviembre de 2012, Rol 5522 -12, MJJ34047. 
con el artículo 19 de la Ley de Urbanismo y Construcción. Según el tribunal de apelación la demanda no estaba basada en la responsabilidad impuesta al primer vendedor, ni tampoco se había intentado la acción redhibitoria, sino sólo una acción indemnizatoria de carácter compensatorio regida por el artículo 1556 del Código Civil. El tribunal impuso a la demandada la obligación de indemnizar los perjuicios derivados de las defectuosas instalaciones de suministro de gas de los inmuebles adquiridos ${ }^{53}$.

También en este sentido, un fallo de 2008 de la Corte Suprema, según el cual el comprador podría interponer como acción principal la indemnización de perjuicios, sin tener que acudir a la acción redhibitoria o de rebaja de precio. La Corte reconoció que el plazo de prescripción de la acción indemnizatoria no es el de la acción redhibitoria ni de la rebaja de precio, sino que se rige por las reglas generales ${ }^{54}$.

Adicionalmente, en un fallo de 27 de mayo de 2010 en el que rechazaron los recursos de casación en el fondo y en la forma interpuestos por el demandado contra una sentencia de segunda instancia, confirmatoria de un fallo que acogió la demanda de indemnización de perjuicios por vicios redhibitorios, consistentes en los defectos que presentaron los baldosines adquidos por la demandante, la Corte Suprema tras analizar las acciones que el Código consagra a partir de los vicios ocultos, afirmó la autonomía de la acción indemnizatoria frente a las otras y estableció que los plazos consagrados en la ley para éstas, no se aplican a la primera ${ }^{55}$.

En igual sentido se pronunció la Corte Suprema en un fallo de 8 de julio de 2010. En este caso, se recurrió en casación un fallo de apelación que confirmó a su vez el de primera instancia que rechazó la demanda de rebaja de precio e indemnización de perjuicios. La Corte casó de oficio la sentencia impugnada. En sus consideraciones afirmó que la indemnización puede ser pedida sin necesidad de asociarla a ninguna de las alternativas de la acción redhibitoria o la quanti minoris, de forma que a

53 Corte de Santiago, 12 de noviembre de 2007, Rol, 5757- 2002, n Legal Publishing: 37654.

54 Corte Suprema, 27 de marzo de 2008, Rol 6700-06, Microiuris.

55 Corte Suprema, 27 de mayo de 2010, Rol 3886-2008, $n^{\circ}$ Legal Publishing: CL/JUR/3822/2010. 
ella se le aplica la norma general sobre prescripción prevista en el artículo 2515 del Código Civil ${ }^{56}$. También en otro caso, la Corte Suprema señaló que la acción indemnizatoria puede interponerse de forma autónoma ${ }^{57}$.

En Colombia, la jurisprudencia ha considerado que el comprador puede formular autónoma e individualmente las acciones edilicias o la de indemnización, o si prefiere acumularlas. Así lo estableció la Corte en un fallo de 1999, a propósito de una demanda en la que el comprador de unos bultos de semillas de arroz demandó una indemnización de perjuicios como consecuencia de que éste no germinó ${ }^{58}$.

El fallo de la Corte Suprema de Justicia de 19 de octubre de 2009 ya citado, consideró también que la acción indemnizatoria se puede interponer de forma autónoma ${ }^{59}$.

56 Corte Suprema, 8 de julio de 2010, Rol 8115-2008, nº Legal Publishing: CL/JUR/5987/201.

57 Corte Suprema, 31 de octubre de 2012, Rol 3325 - 2012, no Legal Publishing: CL/JUR/2412/2012.

58 Corte Suprema de Justicia, Sala de Casación Civil y Agraria, 18 de noviembre de 1999, M.P. José Fernando Ramírez Gómez, exp. 5103, sentencia 092, G.J. CCLXI vol. II, nº 2500, pág. 1011. En crítica a este fallo, Tamayo Lombana, Alberto, El contrato de compraventa, su régimen civil y comercial, Ediciones Doctrina y Ley Ltda., Bogotá, 2004, pág. 191.

59 Corte Suprema de Justicia, 19 de octubre de 2009, cit. 


\section{CONCLUSiones}

Como principales conclusiones expuestas en este trabajo, pueden destacarse las siguientes:

1. En el Código Civil chileno - colombiano, las acciones redhibitoria y de rebaja de precio no exigen dolo ni culpa del vendedor, de forma que comportan una responsabilidad de carácter objetivo por la presencia de los vicios en la cosa objeto del contrato. Por el contrario, la indemnizatoria sí exige dolo o culpa de su parte. Además, tales acciones no indemnizan todo el daño emergente y lucro cesante, sino tienden sólo a dejar indemne al comprador en el precio y un acotado daño emergente representado en el vicio mismo reflejado en la restitución del precio o su rebaja. Por el contrario, la indemnización comprende tanto el daño emergente como el lucro cesante ${ }^{60}$.

2. Se puede adicionar que el supuesto de hecho de cada una de las acciones es diferente: tratándose de las acciones edilicias, se trata de la presencia del vicio en la cosa, con los requisitos ya anotados de ser oculto, anterior al contrato y grave, mientras la indemnización de perjuicios se basa en la inobservancia del deber de información que pesa sobre el vendedor y no en la existencia misma del vicio.

3. Como consecuencia de lo anterior, se puede afirmar que el plazo de prescripción de la acción indemnizatoria no es el especial de la acción redhibitoria o el de la de rebaja de precio, y por tanto en este caso se aplican las normas comunes de prescripción del título XLII libro IV del Código Civil, de cinco años, conforme al artículo 2515 C.C. chil. ${ }^{61}$. De esta forma, el comprador puede interponer la acción indemnizatoria de forma independiente o acumularla bien sea con la acción redhibitoria, la de rebaja de precio, la sustitución o reparación.

60 GuZmán Brito, ob. cit., pág. 103.

61 En este sentido Guzmán Brito, ob. cit., pág. 115. De igual forma en Colombia, Cárdenas Mejía, JuAn PABlo, "La resolución por problemas de funcionamiento de la cosa en el derecho colombiano: el régimen interno - vicios ocultos y garantía mínima presunta - y el régimen de la compraventa internacional de mercaderías", en La terminación del contrato. Nuevas tendencias del Derecho comparado, José Alberto Gaitán Martínez; Fabricio Mantilla Espinosa (directores), Universidad del Rosario, Bogotá, 2007, pág. 246. 
4. La tendencia del Derecho comparado, observada en algunos países de Europa que tienen reglas similares a las del Código Civil chileno - colombiano, consiste en asumir la autonomía de la acción indemnizatoria con las mismas consecuencias ya señaladas. Así mismo, el modelo de falta de conformidad adoptado por instrumentos modernos como la Convención sobre Compraventa Internacional permite al comprador acudir al sistema unitario de remedios por incumplimiento, entre los cuales se encuentra la acción indemnizatoria que bien puede interponerse en conjunto con los otros remedios o de forma independiente.

5. Aun cuando es un tema debatido, doctrina chilena reciente favorece la interpretación de las normas del Código Civil tendientes a predicar la autonomía de la acción indemnizatoria. De igual manera se encuentran decisiones de los tribunales chilenos que han adoptado en los últimos años esta interpretación, por lo cual la posición asumida en algunos fallos consistente en afirmar que para la procedencia de la indemnización por vicios ocultos es requisito el ejercicio previo por el comprador ya sea de la acción redhibitoria o la de rebaja de precio consagradas en el artículo 1860 del Código Civil, además de desconocer argumentos dogmáticos y comparados, desatienden la tendencia jurisprudencial que en los últimos años ha venido asumiendo la autonomía de la acción indemnizatoria.

6. Finalmente, es claro que la acción indemnizatoria por vicios ocultos no comprende los daños que por causa de los mismos se generen en la persona o patrimonio del comprador o terceros, de forma que ésta se debe regir por las reglas generales de responsabilidad, cuyo fundamento puede buscarse en una obligación de seguridad asumido por el vendedor. 


\section{BIBLIOGRAFÍA}

Abeliuk Manasevich, René, Las obligaciones, tomo II, 5ª edición, Editorial Jurídica de Chile, Santiago, 2008.

Agostinis, Barbara, La garanzia per $i$ villi della cosa venduta. Le obligazioni del compratore. Artt. 1490 - 1499, Il Codice Civile, Commentario, fondato da Piero Schlesinger, diretto da Francesco D. Busnelli, Giuffrè, Milano, 2012.

Alessandri Rodríguez, Arturo, De la compra - venta $i$ de la promesa de venta, $\mathrm{t}$. $2^{\circ}$, Imprenta litográfica Barcelona, Santiago, 1918.

Audit, Bernard, La compraventa internacional de mercaderías. Convención de las Naciones Unidas del 11 de abril de 1980, traducción de Ricardo de Zavalía, Zavalía, Buenos Aires, 1994.

Badenes Gasset, Ramón, El contrato de compraventa, tomo 1, $3^{\text {a }}$ edición, José María Bosch editor, Barcelona, 1995

BANFi del Río, CristiÁn, "La asimilación de la culpa grave al dolo en la responsabilidad contractual en Chile", en Revista chilena de Derecho, vol. 27, $\mathrm{n}^{\circ} 2$, (2000), págs. 291 a 300.

BANFI DEL Río, CRISTIÁN, La asimilación de la culpa grave al dolo en la responsabilidad contractual, Lexis Nexis, Santiago, 2003.

Barrientos Zamorano, Marcelo, Daños y deberes en las tratativas preliminares de un contrato, Legal Publishing, Santiago, 2008.

Barros Bourie, Enrique, Tratado de responsabilidad extracontractual, Editorial Jurídica de Chile, Santiago, 2006.

Bénabent, Alain, Droit Civil. Les contrats spéciaux civils et commerciaux, 9e édition, Montcherestien Lextenso éditions, Paris, 2011.

Bianca, Cesare Massimo, La vendita e la permuta, en Trattato di Diritto Civile Italiano fondato da Filipo Vassalli, vol. 7, t. 1, seconda edizione, Utet, Torino, 1993.

Borghetti, Jean - Sébastien, La responsabilité du fait es produts. Étude de droit comparé, LGDJ, Paris, 2004.

Cabella Pisu, Luciana, La reticenza nella formazione del contratti, Cedam, Padova, 1972.

Cárdenas Mejía, Juan Pablo, "La resolución por problemas de funcionamiento de la cosa en el derecho colombiano: el régimen interno - vicios ocultos y garantía mínima presunta - y el régimen de la compraventa internacional de mercaderías", en La terminación del contrato. Nuevas tendencias del Derecho comparado, José Alberto Gaitán Martínez; Fabricio Mantilla Espinosa (directores), Universidad del Rosario, Bogotá, 2007, págs. 217 a 316.

Castán Tobeñas, José, Derecho Civil español común y foral, t. 4, Derecho de obligaciones, las particulares relaciones obligatorias, $15^{\text {a }}$ edición, Reus, Madrid, 1993.

Claro Solar, Luis, Explicaciones de Derecho Civil chileno y comparado, tomo 11, 
De las obligaciones, II, Imprenta Nascimento, Santiago, 1937.

Collart Dutilleul, François; Delebecque, Philippe, Contrats civils et commerciaux, 8 édition, Dalloz, Paris, 2007.

Corral Talciani, Hernán, Contratos y daños por incumplimiento, Abeledo Perrot - Legal Publishing, Santiago, 2010.

Corral Talciani, Hernán, Responsabilidad por productos defectuosos. Análisis y propuestas para el Derecho Civil y de consumo en Chile, Abeledo Perrot Legal Publishing, Santiago, 2011.

Cubides Camacho, Jorge, Obligaciones, $7^{\text {a }}$ edición, Pontificia Universidad Javeriana - Ibañez, Bogotá, 2012.

De la Maza Gazmuri, IÑigo, "A propósito del artículo 1861", en Estudios de Derecho Civil V, Jornadas Nacionales de Derecho Civil, Concepción, 2009, Departamento de Derecho Privado Universidad de Concepción (Coordinador), Abeledo Perrot -Legal Publishing, Santiago, 2010, págs. 455 a 469.

De la Maza Gazmuri, IÑigo, "La distribución del riesgo y la buena fe. A propósito del error, el dolo y los deberes precontractuales de información", en Revista de Derecho de la Pontificia Universidad Católica de Valparaíso, XXXVII, (2011), págs. 115 a 135.

de la Maza Gazmuri, Iñigo, Los límites del deber precontractual de información, Civitas, Cizur Menor, 2010.

Díez Duarte, Raúl, La compraventa, $2^{\mathrm{a}}$ edición actualizada por Eric Andrés Chávez Chávez, El Jurista, Santiago, 2009.

Díez - Picazo, Luis, Fundamentos del Derecho Civil patrimonial. IV. Las particulares relaciones obligatorias, Civitas, Thomson Reuters, Cizur Menor, 2010.

Faure Abbad, Marianne, Le fait générateur de la responsabilité contractuelle, LGDJ, Paris, 2003.

Fueyo Laneri, Fernando, Cumplimiento e incumplimiento de las obligaciones, $3^{\mathrm{a}}$ edición actualizada por el profesor Gonzalo Figueroa-Yáñez, Editorial Jurídica de Chile, Santiago, 2004.

Gómez Estrada, César, De los principales contratos civiles, Temis, $4^{\mathrm{a}}$ edición, Bogotá, 2008.

Guzmán Brito, Alejandro, "Sobre la relación entre las acciones de saneamiento de los vicios redhibitorios y las acciones comunes de indemnización, con especial referencia a su prescripción", en Revista chilena de Derecho Privado, 9, (2007), págs. 95 a 119.

Huet, Jérôme, Les principaux contrats spéciaux, en Traité de Droit Civil sous la direction de Jacques Ghestin, 2e edition, LGDJ, Paris, 2001.

Llácer Matacás, María Rosa, "El dolo en el saneamiento por vicios ocultos", en Anuario de Derecho Civil, t. XLV, f. IV, (1992), págs. 1499 a 1532.

López Díaz, Patricia Verónica, "El interés del deudor como límite al derecho de opción del acreedor insatisfecho y su incidencia en la procedencia de la acción 
de cumplimiento específico y la indemización de daños", en Estudios de Derecho Civil VII, Jornadas nacionales de Derecho Civil Viña del Mar, 2011, Fabián Elorriaga De Bonis (coordinador), Abeledo Perrot Legal Publishing - Thomson Reuters, Santiago, 2012, págs. 737 a 755.

Luminoso, Angelo, La compravendita, sesta edizione, Giappichelli, Torino, 2009.

Markesinis, Basil B.; Unberath, Hannes; Johnston, Angus, The German Law of Contract. A Comparative Treatise, 2nd edition, Hart Publishing, Oregon, 2006.

Mastrorilli, Annachiara, La garanzia per vizi nella vendita. Disciplina del codice civile e del codice di consumo, seconda edizione, Giuffrè, Milano, 2009.

Mazeaud, Henri, "La responsabilité civile du vendeur-fabricant", en RTD Civ., t. Cinquante - troisième, (1955), págs. 611 a 621.

Meza Barros, Ramón, Manual de Derecho Civil. De las obligaciones, 8 a edición, Editorial Jurídica de Chile, Santiago, 1990.

Morales Moreno, Antonio Manuel, "El dolo como criterio de imputación de responsabilidad al vendedor por defectos de la cosa", en Anuario de Derecho Civil, t. XXXV, f. III, (1982), págs. 591 a 684.

Morales Moreno, Antonio Manuel, "Tres modelos de vinculación del vendedor en las cualidades de la cosa", en Anuario de Derecho Civil, t. LXV, f. I, (2012), págs. 5 a 28.

Müller - Chen, Markus, "Article 45", en Commentary on the UN Convention on the International Sale of Goods (CISG), Schlechtriem; Schwenzer / Ingeborg Schwenzer (ed.), $3^{\text {rd }}$ ed., Oxford University Press, Oxford, 2010, págs. 689 a 704 .

Ospina Fernández, Guillermo, Régimen general de las obligaciones, $7^{\mathrm{a}}$ edición, Temis, Bogotá, 2001.

Orti Vallejo, Antonio, La protección del comprador por el defecto de la cosa vendida, Ediciones TAT, Granada, 1987.

Orti Vallejo, Antonio, Los defectos de la cosa en la compraventa civil y mercantil, Comares, Granada, 2002.

Oviedo Albán, Jorge, "Exclusión tácita de la ley aplicable e indemnización de perjuicios por incumplimiento de un contrato de compraventa internacional (a propósito de reciente jurisprudencia chilena", en International Law. Revista colombiana de Derecho Internacional, no 14, (2009), págs. 191 a 219.

Pantaleón Prieto, Fernando, "Las nuevas bases de la responsabilidad contractual", en Anuario de Derecho Civil, t. XLVI, f. IV, (1993), págs. 1719 a 1746.

Pérez Vives, Álvaro, Compraventa y permuta en Derecho colombiano, $2^{\text {a }}$ edición, Temis, Bogotá, 1953.

Pizarro Wilson, Carlos, "La responsabilidad contractual en el Derecho chileno", en Los contratos en el Derecho Privado, Fabricio Mantilla-Espinosa; Francisco Ternera-Barrios, (Directores), Universidad del Rosario, Legis, Bogotá, 2007, págs. 209 a 233. 
Plitz, Bughard, Compraventa internacional. Convención de Viena sobre Compraventa Internacional de Mercaderías de 1980, Astrea, Buenos Aires, 1998.

Rengifo García, ERnesto, “El deber precontractual de información”, en Realidades y tendencias del Derecho en el siglo XXI, Derecho Privado, t. IV, 1, AA. VV., Pontificia Universidad Javeriana, Temis, Bogotá, 2010, págs. 123 a 150.

Rodríguez Fonnegra, Jaime, De la compraventa y materias aledañas, Lerner, Bogotá, 1960.

Rodríguez Grez, Pablo, Responsabilidad contractual, Editorial Jurídica de Chile, Santiago, 2003.

Rojo y Fernández - Rio, Ángel, La responsabilidad civil del fabricante, Publicaciones del Real Colegio de España, Bolonia, 1974.

Rubino, Domenico, La compravendita, en Trattato di Diritto Civile e Commerciale diretto dai professori Antonio Cicu; Francesco Messineo, vol., XXIII, Giuffrè, Milano, 1971.

Tamayo Jaramillo, Javier, Culpa contractual, Temis, Bogotá, 1990.

Tamayo Jaramillo, Javier, Tratado de responsabilidad civil, tomo $1,2^{\text {a }}$ edición, Legis, Bogotá, 2007.

Terranova, Carlo, "La garanzia per vizi e difetti di qualità della cosa venduta", en I Contratti di Vendita, tomo secondo, a cura di Daniela Valentino, Trattato dei contratti, diretto da Pietro Rescigno ed Enrico Gabrielli, Utet, Torino, 2007, págs. 1081 a 1162.

Verda y Beamonte, José Ramón de, Saneamiento por vicios ocultos. Las acciones edilicias, $2^{\mathrm{a}}$ edición, Aranzadi, Cizur Menor, 2009.

Vidal Olivares, Álvaro, La protección del comprador. Régimen de la Convención de Viena y su contraste con el Código Civil, Ediciones Universitarias de Valparaíso, Pontificia Universidad Católica de Valparaíso, Valparaíso, 2006.

Vidal Olivares, Álvaro, "La indemnización de daños y la opción del acreedor frente al incumplimiento", en Estudios de Derecho Civil VI, Jornadas nacionales de Derecho Civil Olmué, 2010, Gonzálo Figueroa Yáñez; Enrique Barros Bourie; Mauricio Tapia Rodríguez (Coordinadores), Abeledo Perrot - Legal Publishing, Santiago, 2011, págs. 763 a 779.

Visintini, Giovanna, La reticenza nella formazione dei contratti, Cedam, Padova, 1972 .

Vodanovic H., Antonio, Tratado de las obligaciones, v. II, basado en las explicaciones de Arturo Alessandri y Manuel Somarriva, $2^{\mathrm{a}}$ edición, Editorial Jurídica de Chile, Santiago, 2004.

Tamayo Lombana, Alberto, El contrato de compraventa, su régimen civil y comercial, Ediciones Doctrina y Ley Ltda., Bogotá, 2004.

Zimmermann, Reinhard, The New German Law of Obligations, Oxford University Press, Oxford, 2005. 


\section{Fallos citados:}

\section{Colombia:}

Corte Suprema de Justicia, Sala de Casación Civil, 13 de junio de 1946, M.P. Manuel José Vargas, G.J., t. LX, pág. 695.

Corte Suprema de Justicia, Sala de Casación Civil, 12 de agosto de 1988, M.P. Héctor Marín Naranjo, G.J., t. CXII, nº 2431.

Corte Suprema de Justicia, Sala de Casación Civil, 11 de septiembre de 1991, M.P. Alberto Ospina Botero, G.J., t. CCXIII, n²451, pág. 120.

Corte Suprema de Justicia, Sala de Casación Civil y Agraria, 18 de noviembre de 1999, M.P. José Fernando Ramírez Gómez, exp. 5103, sentencia 092, G.J. CCLXI vol. II, nº 2500, pág. 1011.

Corte Suprema de Justicia, Sala de Casación Civil, M.P. William Namén Vargas, 19 de octubre de 2009, Ref: 05001-2103-009-2001-00263-01, en Notinet.

\section{Chile:}

Corte Suprema, 13 de enero de 1944, RDJ., t. 42, $2^{\text {a }}$ parte, secc. $1^{\text {a }}$, pág. 25.

Corte de Apelaciones de San Miguel, 27 de enero de 2006, Rol 1605 - 2001, n Lexis Nexis: 35531.

Corte de Apelaciones de Santiago, 31 de octubre de 2006, Rol 6803 - 2001, ${ }^{\circ}$ Legal Publishing: CL/JUR/3524/2006; J3345/2006.

Corte Suprema, 25 de julio de 2007, Rol 6658 - 2005, nº Legal Publishing: 36814.

Corte de Santiago, 12 de noviembre de 2007, Rol, 5757- 2002, n Legal Publishing: 37654.

Corte Suprema, 27 de noviembre de 2007, Rol 2265 - 2006, n Legal Publishing: 37855.

Corte de Apelaciones de Rancagua, 21 de enero de 2008, Rol 828 - 2007, $\mathrm{n}^{\circ}$ Legal Publishing: 38231.

Corte Suprema, 27 de marzo de 2008, Rol 6700 - 06, Microiuris.

Corte Suprema, 27 de mayo de 2010, Rol 3886 - 2008, nº Legal Publishing: CL/ JUR/3822/2010.

Corte Suprema, 8 de julio de 2010, Rol 8115-2008, n $^{\circ}$ Legal Publishing: CL/ JUR/5987/201.

Corte Suprema, 28 de noviembre de 2012, Rol 5522 -12, MJJ34047.

Corte Suprema, 31 de octubre de 2012, Rol 3325 - 2012, nº Legal Publishing: CL/ JUR/2412/2012. 